\title{
Evaluation of the Anti-Viral Activity of Human Recombinant Interferon Lambda-1 against SARS-CoV-2 P. G. Madonov' ${ }^{1}$ V. A. Svyatchenko ${ }^{2}$, S. S. Legostaev², N. A. Kikhtenko ${ }^{1}$, A. A. Kotlyarova ${ }^{1}$, L. A. Oleinik ${ }^{1}$, and G. I. Baikalov ${ }^{1}$
}

Translated from Byulleten'Eksperimental'noi Biologii i Meditsiny, Vol. 172, No. 7, pp. 65-69, July, 2021 Original article submitted April 23, 2021

\begin{abstract}
The antiviral activity of recombinant human IFN-lambda type 1 (IFN $\lambda$-1) against culture strain of SARS-CoV-2 virus was determined by infecting a highly sensitive VeroE6 coronavirus cell culture after preincubation test (the cell monolayer was incubated with 4 -fold dilutions of IFN $\lambda-1$ in a concentration range of $0.16-42,500 \mathrm{ng} / \mathrm{ml}$ in a culture medium for $12 \mathrm{~h}$ at $37^{\circ} \mathrm{C}$ ) and without preincubation (simultaneous addition of different concentrations of IFN $\lambda-1$ and SARS-CoV-2 infection in a dose of $10^{2}$ TCID $_{50}$ ). The created recombinant human IFN $\lambda-1$ demonstrated obvious antiviral activity against SARS-CoV-2 virus in vitro. In the tests with and without preincubation, IFN $\lambda-1$ exhibited significant activity, although somewhat lower in variant with simultaneous addition of IFN $\lambda-1$ and virus to the cell culture. It should be noted that the antiviral effect of IFN $\lambda$ - 1 was observed in a wide range of concentrations.
\end{abstract}

Key Words: SARS-CoV-2; recombinant human interferon $\lambda-1$; specific antiviral activity

Lambda IFNs were discovered in 2003 and are currently defined as type III IFNs. Four representatives of these IFNs have been studied, of these type 1 IFNlambda (IFN $\lambda-1)$ is considered the most promising for clinical practice. According to modern concepts, IFN $\lambda-1$ is a cytokine produced by epithelial cells and providing first-line protection against viral respiratory infections $[4,6]$. This circumstance allows us to consider IFN $\lambda-1$ as a candidate for a drug against the SARS-CoV-2 virus. It was shown that IFN $\lambda-1$ can actively inhibit SARS-CoV-2 replication in primary epithelial cells of the human respiratory tract in $v i$ tro, while preventive and therapeutic administration reduced virus replication in mice [5]. Interestingly, SARS-CoV-2 virus does not induce the expression of type I, II, and III IFNs in infected human lungs [3]. This study does not analyze how SARS-CoV-2 es-

${ }^{1}$ Research Institute of Clinical and Experimental Lymphology - an Affiliated Branch of the Federal Research Centre Institute of Cytology and Genetics, Siberian Division of the Russian Academy of Sciences, Novosibirsk; ${ }^{2}$ State Research Center of Virology and Biotechnology Vector, Federal Service for Surveillance on Consumer Rights Protection and Human Wellbeing, Koltsovo, Novosibirsk region, Russia. Address for correspondence: larisaoleynik81@gmail.com L.A. Oleinik capes the innate immune response and suppresses endogenous IFN production, but the results suggest that treatment with exogenous IFN can be effective against SARS-CoV-2. Meanwhile, IFNs are known to have a potential to increase the expression of type 2 angiotensin-converting enzyme (ACE-2) and can aggravate the course of COVID-19 infection by activating this critical viral entry receptor. Experiments on a cell line model showed that IFN $\beta$ significantly enhances the expression of canonical antiviral ISG pathways in the cytoplasm, as well as ACE-2 on the cell surface. IFN $\gamma$ induced the weakest ISG response, but clearly increased the surface expression of ACE-2. IFN $\lambda-1$ activated antiviral ISG pathways, but ACE- 2 mRNA was increased only slightly and did not lead to an increase in ACE-2 on the cell surface. It is important to note that all types of IFNs inhibited SARS-CoV-2 replication, but IFN $\lambda-1$ exhibited the most powerful antiviral activity in primary epithelial cells of human bronchi.

Thus, there is every reason to believe that recombinant human IFN $\lambda-1$ is a very promising candidate for creation of a drug for effective treatment of COVID-19. 
The objective of the study was to evaluate antiviral activity of newly synthesized recombinant human IFN $\lambda-1$ in cell culture infected with SARS-CoV-2 virus.

\section{MATERIALS AND METHODS}

All studies with infectious viral material were carried out under conditions of BSL3-certified laboratory having a sanitary permit for experimental work with the SARS-CoV-2 virus.

The tested compounds. At the first stage of the development of recombinant human IFN $\lambda$-1, an original producer strain E. coli SG20050/pTINF-lambda with a high level of expression of the target protein was created. Culturing of the producer strain SG20050/pTINF-lambda was carried out in a Biok bioreactor of a gas vortex type with a working volume of 12 liters (Sayany). The protein synthesized by E. coli cells was identified out by Western blotting with polyclonal antibodies to IFN $\lambda-1$. The structure of the recombinant IFN $\lambda 1$ protein was additionally confirmed by MALDI mass spectrometry (MALDI UltraFlex III mass spectrometer, Bruker). Tryptic fragments of the protein were identified both by observing the putative peptides and by searching the obtained tryptic fragments in the Mascot proteomic research database to search for homologous peptide masses. As a result, IFN $\lambda$-1 (IL-29) was identified, its amino acid sequence IFN $\lambda-1$ corresponds to the cloned nucleotide sequence of the gene. The molecular weight of IFN $\lambda-1(20,125.75 \mathrm{Da}, \sim 20.1 \mathrm{kDa})$ was determined by electrophoresis (VE-2M vertical electrophoresis chamber; Helikon) and mass spectrophotometry (MALDI UltraFlex III mass spectrometer). The purity of the obtained IFN $\lambda-1$ preparation was 97.77\% (liquid chromatograph ActaPurifier100, GE Healthcare).

Evaluation of antiviral activity. Antiviral activity of IFN $\lambda$ - 1 was assessed using the culture strain of the SARS-CoV-2 virus isolated in 2020 at the State Research Center of Virology and Biotechnology Vector from a clinical sample of a patient infected with the new coronavirus. The cultured SARS-CoV-2 virus was obtained as a result of infection of VeroE6 cell culture highly susceptible to coronaviruses. The authenticity of the isolated SARS-CoV-2 virus strain was confirmed by PCR analysis and genome-wide sequencing. The virus-containing culture fluid was purified and concentrated by centrifugation in a cell with a cut-off VivaSpin-20 centrifugal filter $(100 \mathrm{kDa}$; Sartorius). The infectious activity of the viral effluent was determined by the micro method, titration on 96well culture plates (Greiner bio-one $\mathrm{GmbH}$ ) with subconfluent VeroE6 cells monolayer. For this purpose, the cell monolayer was infected with 10 -fold dilutions of the virus, and after 3 -day incubation at $37^{\circ} \mathrm{C}$ and $5 \% \mathrm{CO}_{2}$, the results were evaluated by microscopy (by virus-specific cytopathogenic effect) and using a test of metabolic activity of cells (MTT-assay). The infectious titer of the virus was expressed in terms of $\mathrm{TCID}_{50}(50 \%$ tissue culture infective dose). The titer of the viral effluent was $\sim 5 \times 10^{7} \mathrm{TCID}_{50} / \mathrm{ml}$. The stock was aliquoted $(50 \mu \mathrm{l}$ aliquots $)$ and stored at $-80^{\circ} \mathrm{C}$ until use. The resulting stock of cultured SARS-CoV-2 virus was used to determine the antiviral activity of IFN $\lambda-1$

At the first step, the analysis of the possible cytotoxic activity of IFN $\lambda-1$ in a VeroE6 cell culture at concentrations of $0.16-42,500 \mathrm{ng} / \mathrm{ml}$ was carried out. The cytotoxic activity of IFN $\lambda-1$ was determined by the micromethod on 96-well plates (Greiner bio-one $\mathrm{GmbH}$ ) using the MTT assay. Formazan dissolution and spectrophotometry allowed accurate correlation of change in optical density with changes in the number of viable cells. The specific death of cells treated with different concentrations of the test IFN preparations ( 2 series) relative to untreated control $(100 \%$ viability) was assessed. Each measurement of optical density was performed in three repetitions.

To determine the antiviral activity of IFN $\lambda-1$, a monolayer of VeroE6 cells grown in 96-well plates was incubated with 4-fold dilutions of IFN $\lambda-1$ in a concentration range of $0.16-42,500 \mathrm{ng} / \mathrm{ml}$ in culture medium for $12 \mathrm{~h}$ at $37^{\circ} \mathrm{C}$. Then, the cells were infected with the same dose of SARS-CoV-2 virus (frozen stock) in a dose of $10^{2} \mathrm{TCID}_{50} /$ well (except for the control of cells), each dilution of interferon was tested in 3 wells. The plates were incubated for 3 days at $37^{\circ} \mathrm{C}$ in a $\mathrm{CO}_{2}$ incubator, then the results were recorded by microscopy according to the severity of cytopathic effect (CPE) and by recording cell viability by MTT analysis (optical density at spectrophotometry). The antiviral activity of IFN $\lambda-1$ in vitro was expressed through $50 \%$ inhibitory concentration $\left(\mathrm{IC}_{50}\right)[1,7]$.

The antiviral activity in the test without preincubation was determined in a similar way, but different concentrations of IFN $\lambda-1$ were added to cells simultaneously with the virus.

Statistical analysis. The obtained data were statistically processed using the Statistica 12 software (StatSoft, Inc.). After measuring optical density, the mean and the error of the mean were calculated $(M \pm m)$.

\section{RESULTS}

Analysis of possible cytotoxic activity of IFN $\lambda-1$ against VeroE6 cell culture in a concentration range 
of $0.16-42,500 \mathrm{ng} / \mathrm{ml}$ revealed no significant cytotoxic effect in comparison with the control of cells even at the maximum dose.

Antiviral activity of IFN $\lambda-1$ on the monolayer of VeroE6 cells in the test with preincubation are presented in Table $1 . \mathrm{IC}_{50}$ of IFN $\lambda-1$ was $6.4 \pm 2.9 \mathrm{ng} / \mathrm{ml}$. Hence, the therapeutic index in vitro (ratio of $\mathrm{CC}_{50}$ to $\mathrm{IC}_{50}$ ) was $>4000$.

IFN $\lambda-1$ in a concentration of $10.3 \mathrm{ng} / \mathrm{ml}$ provided complete protection of the cell monolayer; at a concentration of $2.5 \mathrm{ng} / \mathrm{ml}$, single foci of virus-specific cytopathogenic effect were observed (30-40\% monolayer area) (Fig. 1). In cell monolayers incubated with a concentration of $0.62 \mathrm{ng} / \mathrm{ml}, 100 \%$ cell death (lysis) was noted. These data indicate that IFN $\lambda-1$, even in a concentration of $2.5 \mathrm{ng} / \mathrm{ml}$, effectively inhibited infectivity of SARS-CoV-2 in vitro.

Activity of IFN $\lambda$-1 without preincubation (simultaneous addition of different concentrations of IFN $\lambda-1$ to cell monolayers and infection with SARS-CoV-2 in a dose of $10^{2} \mathrm{TCID}_{50}$ ) was lower than in the test with preincubation (Table 2). $\mathrm{IC}_{50}$ of IFN $\lambda$-1 was $14,250 \pm 4300 \mathrm{ng} / \mathrm{ml}$. Complete inhibition of viral infectivity was not achieved even at the maximum concentration of IFN $\lambda-1(42,500 \mathrm{ng} / \mathrm{ml})$. At the same time, in samples with concentrations of 2656 and $664 \mathrm{ng} / \mathrm{ml}$ IFN $\lambda-1$, some cells retained their viability, and the monolayer partially recovered by 6-8 days in culture. This suggests that IFN $\lambda-1$ added simultaneously with infection, produced significant, though less pronounced than in the test with preincubation, antiviral activity against SARS-CoV-2 virus. It is likely that a more pronounced activity of IFN $\lambda-1$ can be detected in case of cell infection with a lower dose of the virus, although the use of $10^{2} \mathrm{TCID}_{50}$ is standard for such experiments.

Thus, the synthesized recombinant human IFN $\lambda-1$ has obvious antiviral activity against SARS-CoV-2 virus in vitro. The antiviral effect of IFN $\lambda-1$ was observed in a wide concentration range. After preliminary addition of IFN $\lambda-1$ to cells and $12-\mathrm{h}$ preincubation prior to infection, ID $_{50}$ of IFN $\lambda-1$ was observed at low concentrations $(6.4 \pm 2.9 \mathrm{ng} / \mathrm{ml})$. In the test without preincubation, it was shown that IFN $\lambda-1$ exhibits less pronounced, but at the same time significant activity. It can be hypothesized that in case of the simultaneous exposure of the cell culture to the virus and IFN $\lambda-1$, interferon activates the antiviral defense mechanism, but does not have time to fully implement it. However, one should consider the fact that in this experiment the concentration of viral particles was quite high, and at lower virus concentration, the effectiveness of IFN $\lambda$ - 1 under conditions simultaneous administration can increase. The results of our experiments provide the basis for further research aimed at creation of
TABLE 1. Antiviral Activity of IFN $\lambda-1$ in VeroE6 Cell Culture in the Test with Preincubation $(M \pm m)$

\begin{tabular}{l|c|c}
\hline $\begin{array}{l}\text { Concentration of } \\
\text { IFN } \lambda-1, \mathrm{ng} / \mathrm{ml}\end{array}$ & $\begin{array}{c}\text { Monolayer } \\
\text { integrity }\end{array}$ & $\begin{array}{c}\text { Optical density } \\
\left(\mathrm{OD}_{540}\right)\end{array}$ \\
\hline $\begin{array}{l}\text { Cell control } \\
\text { (intact cells) }\end{array}$ & +++ & $1.20 \pm 0.20$ \\
$\begin{array}{l}\text { Virus control } \\
\text { (infected cells) }\end{array}$ & - & $0.14 \pm 0.09$ \\
42,500 & +++ & $1.10 \pm 0.15$ \\
10,625 & +++ & $1.25 \pm 0.20$ \\
2656 & +++ & $1.15 \pm 0.17$ \\
664 & +++ & $1.10 \pm 0.13$ \\
166 & +++ & $1.17 \pm 0.15$ \\
41.5 & ++ & $1.22 \pm 0.21$ \\
10.3 & ++ & $1.12 \pm 0.15$ \\
2.5 & + & $0.55 \pm 0.12^{+0}$ \\
0.62 & - & $0.16 \pm 0.10^{+}$ \\
0.16 & - & $0.18 \pm 0.10$ \\
\hline
\end{tabular}

Note. *Inhibition of the lytic activity of the virus by IFN $\lambda-1$ was evaluated relative to $100 \%$ infection (death of VeroE6 cell monolayer). +++ unchanged VeroE6 monolayer, ++ single foci of CPE, $+40-60 \%$ $\mathrm{CPE}$; - complete destruction of the VeroE6 monolayer. $p<0.05$ in comparison with +virus control, olFN $\lambda-1$ concentration of $0.62 \mathrm{ng} / \mathrm{ml}$.

TABLE 2. Antiviral Activity of IFN $\lambda-1$ in VeroE6 Cell Culture in the Test without Preincubation $(M \pm m)$

\begin{tabular}{l|c|c}
\hline $\begin{array}{l}\text { Concentration of } \\
\text { IFN } \lambda-1, \mathrm{ng} / \mathrm{ml}\end{array}$ & $\begin{array}{c}\text { Monolayer } \\
\text { integrity }\end{array}$ & $\begin{array}{c}\text { Optical density } \\
\left(\mathrm{OD}_{540}\right)\end{array}$ \\
\hline $\begin{array}{l}\text { Cell control } \\
\text { (intact cells) }\end{array}$ & +++ & $1.25 \pm 0.22$ \\
$\begin{array}{l}\text { Virus control } \\
\text { (infected cells) }\end{array}$ & - & $0.18 \pm 0.14$ \\
42,500 & + & $0.60 \pm 0.20$ \\
10,625 & - & $0.55 \pm 0.13^{+0}$ \\
2656 & - & $0.18 \pm 0.12^{+}$ \\
664 & - & $0.20 \pm 0.13$ \\
166 & - & $0.19 \pm 0.15$ \\
41.5 & - & $0.18 \pm 0.11$ \\
10.3 & - & $0.15 \pm 0.15$ \\
2.5 & - & $0.12 \pm 0.10$ \\
0.62 & - & $0.16 \pm 0.14$ \\
0.16 & - & $0.14 \pm 0.15$ \\
\hline
\end{tabular}

Note. *Inhibition of the lytic activity of the virus by IFN $\lambda-1$ was evaluated relative to $100 \%$ infection (death of VeroE6 cell monolayer). +++ unchanged VeroE6 monolayer, + 40-60\% CPE; - complete destruction of the VeroE6 monolayer. $p<0.05$ in comparison with ${ }^{+}$virus control, 이 $\mathrm{N} \lambda-1$ concentration of $2656 \mathrm{ng} / \mathrm{ml}$. 

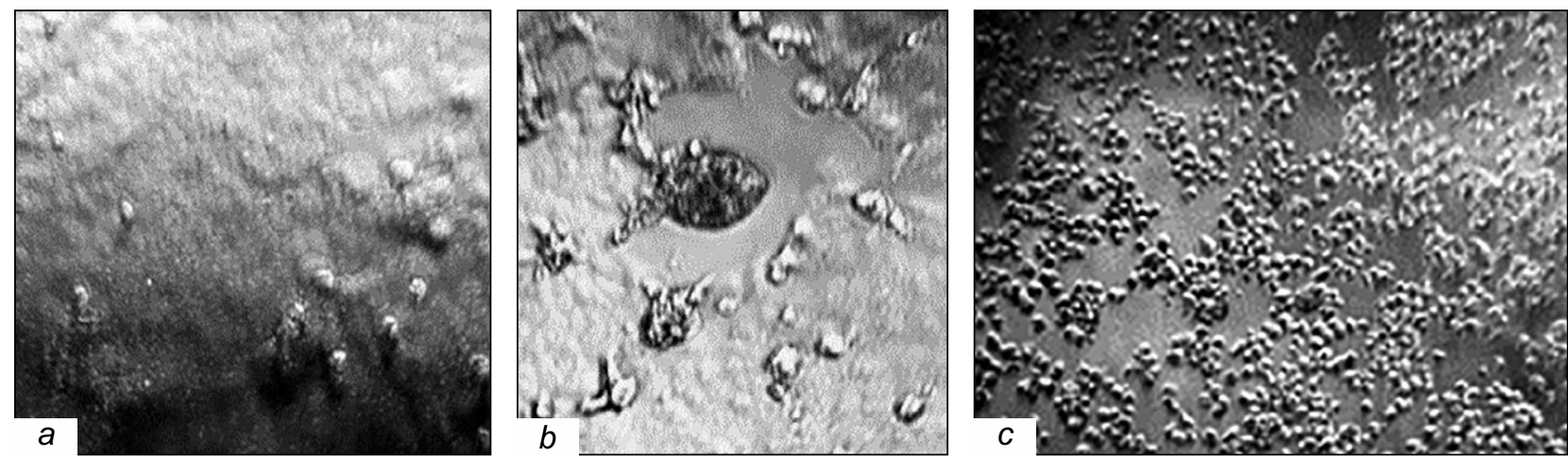

Fig. 1. Monolayers of VeroE6 cells preincubated with IFN $\lambda-1$ in concentrations of $10.3 \mathrm{ng} / \mathrm{ml}(a), 2.5 \mathrm{ng} / \mathrm{ml}(b), 0.62 \mathrm{ng} / \mathrm{ml}(c)$ and infected with $10^{2}$ TCID $_{50}$ SARS-CoV-2, $\times 100$.

optimal pharmaceutical substances and dosage forms of IFN $\lambda-1$.

\section{REFERENCES}

1. Kirilyuk IA, Svyatchenko VA, Morozov DA, Kazachinskaya EI, Kiselev NN, Bakunova SM, Voinov MA, Loktev VB, Grigoryev IA. In vitro cytotoxicity of nitroxyl radicals with respect to tumor and diploid human cells and estimation of their antiviral activity. Antibiotiki Khimioterapiya. 2012;57(12):3-12. Russian.

2. Busnadiego I, Fernbach S, Pohl MO, Karakus U, Huber M, Trkola A, Stertz S, Hale BG. Antiviral activity of type I, II, and III interferons counterbalances ACE2 inducibility and restricts SARS-CoV-2. mBio. 2020;11(5):e01928-20. doi: 10.1128/ mBio.01928-20

3. Dinnon KH 3rd, Leist SR, Schäfer A, Edwards CE, Martinez DR, Montgomery SA, West A, Yount BL Jr, Hou YJ, Adams LE, Gully KL, Brown AJ, Huang E, Bryant MD, Choong IC, Glenn JS, Gralinski LE, Sheahan TP, Baric RS. A mouse-adapted model of SARS-CoV-2 to test COVID-19 countermeasures. Nature. 2020;586:560-566. doi: 10.1038/s41586-020-2708-8
4. O'Brien TR, Thomas DL, Jackson SS, Prokunina-Olsson L, Donnelly RP, Hartmann R. Weak Induction of interferon expression by severe acute respiratory syndrome coronavirus 2 supports clinical trials of interferon- $\lambda$ to treat early coronavirus disease 2019. Clin. Infect. Dis. 2020;71(6):1410-1412. doi: $10.1093 / \mathrm{cid} / \mathrm{ciaa} 453$

5. Peignier A, Parker D. Pseudomonas aeruginosa can degrade interferon $\lambda$, thereby repressing the antiviral response of bronchial epithelial cells. J. Interferon Cytokine Res. 2020;40(8):429431. doi: 10.1089/jir.2020.0057

6. Salka K, Arroyo M, Chorvinsky E, Abutaleb K, Perez GF, Wolf S, Xuchen X, Weinstock J, Gutierrez MJ, Pérez-Losada M, Pillai DK, Nino G. Innate IFN-lambda responses to dsRNA in the human infant airway epithelium and clinical regulatory factors during viral respiratory infections in early life. Clin. Exp. Allergy. 2020;50(9):1044-1054. doi: 10.1111/ cea. 13701

7. Svyatchenko VA, Nikonov SD, Mayorov AP, Gelfond ML, Loktev VB. Antiviral photodynamic therapy: Inactivation and inhibition of SARS-CoV-2 in vitro using methylene blue and Radachlorin. Photodiagnosis Photodyn. Ther. 2021;33:102112. doi: 10.1016/j.pdpdt.2020.102112 